\title{
Model Pembelajaran Kooperatif Tipe Team Assisted Individualization (TAI) Pada Pembelajaran Teknik Dasar Lompat Jauh
}

\section{Cooperative Learning Model Using Team Assisted Individualization (TAl) Type in Learning the Long Jump Basic Technique}

\author{
I Komang Adi Palgunadi', Putu Citra Permana Dewi², Kadek Dian Vanagosi³ I Made Bagia4 \\ 1,2,3,4Fakultas Keguruan dan IImu Pendidikan, Universitas PGRI Mahadewa Indonesia, Indonesia \\ email: adimang328@gmail.com¹,putucitrapermanadewi@gmail.com²,kadekvanagosi@gmail.com³,
} made.bagia123@gmail.com

doi: https://doi.org/10.20884/1.paju.2021.2.2.4055

\begin{abstract}
Abstrak
Gaya lompatan dalam pembelajaran lompat jauh masing-masing memiliki karakteristik dan tingkat kesulitan yang berbeda untuk dipelajari. Faktor kognitif siswa memberikan kontribusi dalam memahami teknik berlari, menolak dan mendarat dalam lompat jauh. Observasi awal yang dilakukan di kelas VIII D SMP Negeri 1 Sawan belum memenuhi kriteria ketuntasan klasikal. Permasalahan yang terjadi proses pembelajaran masih individu dan waktu koreksi dari guru yang minim. Sehingga perlu model pembelajaran yang menempatkan siswa dengan kemampuan berbeda-beda dalam kelompok belajar. Tujuan penelitian untuk meningkatkan hasil belajar teknik dasar lompat jauh pada siswa kelas VIII D SMP Negeri 1 Sawan tahun pelajaran 2019/2020 dengan mengimplementasikan model pembelajaran kooperatif tipe team assisted individualization. Penelitian ini merupakan penelitian tindakan kelas, pelaksanaan penelitian dalam 2 siklus, terdiri dari perencanaan, pelaksanaan, evaluasi, dan refleksi. Subjek penelitian 37 siswa, terdiri dari 16 siswa putra dan 21 siswa putri. Data dianalisis menggunakan statistik deskriptif. Hasil analisis data pada siklus I menunjukkan persentase ketuntasan hasil belajar teknik dasar lompat jauh secara klasikal $89,18 \%$. Sedangkan pada siklus II menunjukkan rata-rata persentase ketuntasan hasil belajar teknik dasar lompat jauh secara klasikal $94,59 \%$. Kesimpulan penelitian bahwa hasil belajar teknik dasar lompat jauh meningkat melalui penerapan model pembelajaran kooperatif tipe team assisted individualization pada siswa kelas VIII D SMP Negeri 1 Sawan tahun pelajaran 2019/2020.
\end{abstract}

Kata Kunci : Pembelajaran Kooperatif, Team Assisted Individualization, Lompat Jauh

\footnotetext{
Abstract

Each jumping style in long jump technique has different characteristics and difficulty levels to learn. Students' cognitive factors contribute to understanding running, attack until take off and landing techniques in the long jump. Oservation in class VIII D of SMP Negeri 1 Sawan did not meet the classical completeness criteria. The problems that occur in the learning process are still individual and few time for correction from the teacher. So that we need a learning model that Alamat Koresponden : Fakultas Keguruan dan IImu Pendidikan, Universitas PGRI Mahadewa Indonesia, Indonesia

Email : putucitrapermanadewi@gmail.com
} 
places students with different abilities in study groups This study aims to improve learning outcomes of the basic long jump technique in students grade VIII D of SMP Negeri 1 Sawan in the 2019/2020 academic year by implementing a team-assisted individualization cooperative learning model. The method uses classroom action research in 2 cycles, consisted of planning, implementation, evaluation, and reflection. The research subjects were 37 students, consisted of 16 male students and 21 female students. Data were analysed using descriptive statistics. The results of study in the first cycle showed the percentage of completeness of the classical long jump basic technique learning outcomes of $89.18 \%$. Whereas in the second cycle, the average percentage of completeness of the learning outcomes of the classical long jump basic techniques was $94.59 \%$. The conclusion of the study is that the learning outcomes of the basic long jump technique increased through the application of the team assisted individualization cooperative learning model in students grade VIII D of SMP Negeri 1 Sawan in the 2019/2020 academic year.

Keywords : Cooperative Learning, Team Assisted Individualization, Long Jump

\section{PENDAHULUAN}

Pendidikan jasmani olahraga dan kesehatan (penjasorkes) pada dasarnya merupakan bagian integral dari sistem pendidikan secara keseluruhan. Menurut Rosdiani (2012), pendidikan jasmani merupakan proses pendidikan yang memanfaatkan aktivitas jasmani yang direncanakan secara sistematis untuk mengembangkan dan meningkatkan individu secara organik, neumuskuler, perseptual, kognitif, dan emosional. Ciri dari pendidikan jasmani adalah belajar melalui pengalaman gerak untuk mencapai tujuan pengajaran melalui pelaksanaan, aktivitas jasmani, bermain dan olahraga (Mulyanto, 2014). Saat ini pendidikan jasmani di sekolah lebih dikenal dengan penjasorkes. Penjasorkes merupakan suatu proses pembelajaran yang didesain untuk meningkatkan kebugaran jasmani, mengembangkan keterampilan motorik, pengetahuan dan prilaku hidup aktif dan sikap sportif melalui kegiatan jasmani.

Melalui penjasorkes diharapkan siswa dapat memperoleh berbagai pengalaman untuk mengungkapkan kesan pribadi yang menyenangkan, kreatif, inovatif, terampil, meningkatkan dan memelihara kebugaran jasmani. Proses pembelajaran penjasorkes biasanya dilakukan dengan menerapkan beberapa model pembelajaran yang dapat membantu siswa selama proses pembelajaran. Hasil penelitian yang dilakukan oleh Indrawathi et al. (2021) tentang faktor-faktor yang mempengaruhi hasil belajar pendidikan jasmani, olahraga dan kesehatan pada siswa sekolah menengah pertama, bahwa faktor pendekatan belajar kadang mempengaruhi hasil belajar siswa sekolah menengah 
I Komang Adi Palgunadi, Putu Citra Permana Dewi, Kadek Dian Vanagosi \& I Made Bagia | Model Pembelajaran Kooperatif Tipe Team Assisted Individualization (TAI) Pada Pembelajaran Teknik Dasar Lompat Jauh

pertama. Oleh sebab itu, pemilihan metode pembelajaran yang tepat berdasarkan kondisi siswa sangat diperlukan.

Salah satu model pembelajaran yang dapat digunakan yaitu model pembelajaran kooperatif yang merupakan rangkaian kegiatan belajar dalam kelompok-kelompok tertentu untuk mencapai tujuan pembelajaran. Pembelajaran kooperatif adalah model pembelajaran yang berfokus pada penggunaan kelompok kecil siswa untuk bekerja sama dalam memaksimalkan kondisi belajar sehingga mencapai tujuan belajar (Budi \& Listiandi, 2021; Nur et al., 2020; Sugiyanto, 2010)). Tipe model pembelajaran kooperatif menurut Slavin (2005) yaitu Student Teams-Achievement Division (STAD), Team Game Tournament (TGT), Jigsaw II, Cooperative Integrated Reading and Composition (CIRC), Team Assisted Individualization (TAI), Group Investigation, Learning Together, Complex Instruction, dan Structure Dyadic Methods.

Model pembelajaran kooperatif tipe team assisted individualization merupakan kombinsai keunggulan pembelajaran kooperatif dan individual. Pada model pembelajaran ini masing-masing siswa akan belajar secara individual yang kemudian hasil belajar tersebut dibawa ke kelompok dan didiskusikan serta dibahas oleh anggota kelompok. Miftakhul (2011) menjelaskan dalam model pembelajaran team assisted individualization, siswa dikelompokkan berdasarkan kemampuannya yang beragam, yang terdiri dari 5 siswa dan ditugaskan untuk menyelesaikan materi pembelajaran. Model pembelajaran ini terikat pada serangkaian materi pelajaran yang khas dan memiliki petunjuk pelaksanaan sendiri. Model pembelajaran team assisted individualization terdiri dari delapan komponen yaitu 1) mempelajari materi pelajaran, 2) tes penempatan (placement test), 3) membagi siswa ke dalam kelompok, 4) belajar kelompok (study teams), 5) skor dan penghargaan kelompok, 6) refleksi, 7) tes akhir, dan 8) unit keseluruhan (Asma, 2006).

Beberapa penelitian telah dilakukan untuk mengetahui efektivitas model pembelajaran kooperatif tipe team assisted individualization (TAI) dalam peningkatan hasil belajar siswa. Penelitian yang dilakukan oleh Cahyaningsih (2016) tentang penerapan model pembelajaran TAI pada pembelajaran bola basket memperoleh hasil yang positif, hasil belajar passing bola basket siswa SMPN 14 Surakarta meningkat dengan menerapkan model pembelajaran TAI. Penelitian tentang penggunaan model TAI untuk meningkatkan hasil belajar juga dilakukan oleh Ishak \& Supriadi (2018) hasil penelitian menunjukkan bahwa model pembelajaran TAI memberikan pengaruh yang signifikan 
dalam meningkatkan hasil belajar teknik shooting bagian punggung kaki pada siswa. Penelitian lain dengan subjek penelitian siswa SMP dilakukan oleh Palgunadi \& Putra (2020) tujuan penelitian untuk meningkatkan hasil belajar teknik dasar menggiring bola pada siswa kelas VIII K SMP Negeri 1 Mengwi tahun pelajaran 2018/2019. Hasil penelitian menyatakan hasil belajar teknik dasar menggiring kaki dalam dapat ditingkatkan melalui penerapan model pembelajaran kooperatif tipe TAI pada siswa kelas VIII K SMP Negeri 1 Mengwi tahun pelajaran 2018/2019. Metode ini juga berhasil membantu meningkatkan hasil belajar teknik dribbling bola basket pada siswa SMA Negeri 5 Kota Tanjung Balai (Bari, 2017). Berdasarkan hasil beberapa penelitian tersebut dapat dilihat bahwa model pembelajaran TAl efektif untuk meningkatkan hasil belajar penjas khususnya pada siswa SMP.

Berdasarkan observasi awal yang peneliti lakukan di kelas VIII D SMP Negeri 1 Sawan dengan jumlah siswa 37 orang dan berpedoman pada konversi nilai mata pelajaran penjasorkes SMP Negeri 1 Sawan, ketuntasan secara individu 70\%, ketuntasan klasikal $75 \%$ maka, dari data persentase di kelas VIII D2 SMP Negeri 1 Sawan tingkat ketuntasan klasikalnya baru mencapai $62,16 \%$ sehingga belum memenuhi kriteria ketuntasan klasikal $75 \%$. Sedangkan data persentase hasil belajar teknik dasar lompat jauh yaitu 3 orang sangat baik (8,11\%), 1 orang baik (2,71\%), 19 orang cukup (51,35\%), dan 14 orang kurang $(37,83 \%)$. Pentingnya penelitian ini antara lain untuk memperbaiki motivasi dan hasil belajar siswa pada pembelajaran penjasorkes khususnya pada teknik dasar lompat jauh.

Lompat jauh merupakan salah satu nomor pada olahraga atletik. Gerakan lompat jauh dimulai dari awalan dengan gerak vertikal yang dihasilkan dari kaki tumpu dan menghasilkan gerak parabola (Djumidar, 2007). Pada pembelajaran lompat jauh terdapat tiga gaya yaitu gaya jongkok, gaya menggantung, gaya berjalan di udara (Purnomo, 2011). Setiap gaya memiliki karakteristik yang berbeda-beda untuk dipelajari. Terutama pada permasalahan-permasalahan yang sering dihadapi oleh siswa pada saat mengikuti mata pelajaran penjasorkes maupun permasalahan-permasalahan yang dihadapi oleh guru penjasorkes dalam merapkan metode-metode pembelajaran.

Berdasarkan masalah itu, peneliti akan mencoba memberikan salah satu alternatif pemecahan masalah yaitu dengan menerapkan model pembelajaran kooperatif tipe team assisted individualization yang bertujuan untuk mengajak siswa lebih berperan aktif dalam proses pembelajaran teknik dasar Lompat Jauh. TAl adalah salah satu pembelajaran 
I Komang Adi Palgunadi, Putu Citra Permana Dewi, Kadek Dian Vanagosi \& I Made Bagia | Model Pembelajaran Kooperatif Tipe Team Assisted Individualization (TAl) Pada Pembelajaran Teknik Dasar Lompat Jauh

kooperatif yang menempatkan siswa dalam kelompok belajar, yang siswanya memiliki kemampuan yang heterogen atau berbeda tingkat kecepatannya menerima pelajaran dan memecahkan permasalahan yang diberikan.

\section{METODE}

Jenis penelitian yang digunakan dalam penelitian ini adalah Penelitian Tindakan Kelas (PTK). Penelitian tindakan kelas merupakan bagian dari penelitian tindakan yang dilakukan oleh guru dan dosen di kelas (sekolah dan perguruan tinggi) tempat mengajar yang bertujuan memperbaiki dan meningkatkan kualitas dan kuantitas proses pembelajaran di kelas (Budi, et al., 2019; Iskandar, 2015). Oja (dalam Kanca, 2010) mengatakan bahwa ada empat bentuk penelitian tindakan kelas yaitu (1) guru sebagai peneliti, (2) penelitian tindakan kolaboratif, (3) simultan terintegrasi, dan (4) administrasi sosial eksperimental. Bentuk penelitian tindakan kelas yang akan digunakan adalah guru sebagai peneliti, yaitu guru dalam hal ini peneliti berperan sangat penting dalam proses PTK karena terlibat secara penuh dalam proses perencanaan, tindakan, dan refleksi. Dalam penelitian tindakan kelas ini direncanakan sebanyak dua siklus yang terdiri dari enam tahapan, yaitu: (1) obsevasi awal, (2) refleksi awal, (3) Perencanaan, (4) tindakan, (5) evaluasi, dan (6) refleksi.

Subjek penelitian yaitu 37 siswa kelas VIII D SMP Negeri 1 Sawan, terdiri dari 16 siswa putra dan 21 siswa putri. Langkah-langkah model pembelajaran kooperatif tipe TAI pada pembelajaran teknik dasar lompat jauh yang diberikan dijelaskan pada tabel 1.

Tabel 1. Langkah-langkah Pembelajaran Kooperatif Tipe TAI pada Pembelajaran Teknik Dasar Lompa Jauh

\begin{tabular}{lll}
\hline \multicolumn{2}{c}{ Fase } & \multicolumn{2}{c}{ Proses Belajar dan Pembelajaran } \\
\hline 1. & Mempelajari materi & \multicolumn{2}{c}{ Guru menyajikan materi pembelajaran teknik dasar lompat jauh } \\
& pelajaran & $\begin{array}{l}\text { kepada siswa. Siwa mempelajari materi pelajaran yang telah } \\
\text { disiapkan oleh guru. }\end{array}$ \\
\hline 2. & Tes penempatan & Siswa mengerjakan tes awal secara individu, untuk megetahui \\
& (placement test) & kemampuan awal siswa. \\
\hline 3. & Membagi siswa ke & Berdasarkan hasil tes awal siswa dibagi menjadi 7 kelompok terdiri \\
& dalam kelompok & dari 5-6 orang dengan kemampuan yang heterogen. \\
\hline 4. & Belajar kelompok & Setiap kelompok mendiskusikan materi yang sudah dipelajari oleh \\
& (study teams) & masaing-masing individu. Guru membimbing kelompok-kelompok \\
& & belajar dalam mempelajari teknik dasar lompat jauh.
\end{tabular}




\begin{tabular}{|c|c|c|}
\hline 5. & $\begin{array}{l}\text { Skor dan } \\
\text { penghargaan } \\
\text { kelompok }\end{array}$ & $\begin{array}{l}\text { Guru mengevaluasi hasil belajar teknik dasar lompat jauh secara } \\
\text { kelompok dan individu. Kelompok yang mendapatkan akumulasi nilai } \\
\text { individu tertinggi diberikan penghargaan, sedangkan yang masih } \\
\text { kurang diberikan motivasi untuk lebih giat lagi. }\end{array}$ \\
\hline & Refleksi & $\begin{array}{l}\text { Guru memberikan penegasan terhadap materi yang sudah dipelajari, } \\
\text { sehinga siswa lebih mantap terhadap materi yang teknik dasar } \\
\text { lompat jauh. }\end{array}$ \\
\hline & Tes akhir & $\begin{array}{l}\text { Guru memeberikan tes akhir yang dikerjakan secara individu berupa } \\
\text { unjuk kerja untuk menilai pemahamam siswa terhadap materi teknik } \\
\text { dasar lompat jauh. }\end{array}$ \\
\hline & Unit keseluruhan & $\begin{array}{l}\text { Pada akhir pembelajaran guru melakukan evaluasi berdasarkan hasil } \\
\text { tes akhir siswa. }\end{array}$ \\
\hline
\end{tabular}

(Sumber: Dimodifikasi dari Slavin, 2005)

Metode pengumpulan data yang digunakan adalah assesmen hasil belajar gaya dalam lompat jauh dan teks keterampilan gaya jongkok dan gaya menggantung. Data dianalisis menggunakan statistik deskriptif. Adapun untuk bentuk lembar observasi dan assesmen yang digunakan diambil dari Syarifuddin (1997) dengan menggunakan format pengamatan sesuai dengan aspek yang diamati. Data hasil belajar siswa secara individu (nilai akhir) dianalisis dengan menggunakan rumus skor hasil tes dibagi skor maksimal ideal dikaliakn dengan nilai ideal dalam skala 100 (Nurhasan, 1990). Tingkat ketuntasan belajar secara klasikal menggunakan rumus jumlah siswa tuntas dibagi jumlah siswa keseluruhan dikali 100\%. Penelitian tindakan kelas untuk mengetahui motivasi dan hasil belajar siswa ini dikatakan berhasil apabila motivasi dan hasil belajar siswa minimal berada pada kategori ketutasan Penilaian Pedoman Acuan (PAP), baik secara individu maupun klasikal.

\section{HASIL}

\section{Hasil Penelitian Siklus I}

Berdasarkan analisis data hasil belajar teknik dasar lompat jauh gaya jongkok menggunakan model pembelajaran kooperatif tipe TAl pada Siklus I dapat dikelompokkan dalam kategori pada tabel 2. dibawah ini. 
I Komang Adi Palgunadi, Putu Citra Permana Dewi, Kadek Dian Vanagosi \& I Made Bagia | Model Pembelajaran Kooperatif Tipe Team Assisted Individualization (TAI) Pada Pembelajaran Teknik Dasar Lompat Jauh

Tabel 2. Persentase Kategori Ketuntasan Hasil Belajar Secara Individu Lompat Jauh Gaya Jongkok Siswa Kelas VIII D2 SMP Negeri 1 Sawan pada Siklus I

\begin{tabular}{|c|c|c|c|c|c|}
\hline Kategori & Jumlah & Persentase & $\begin{array}{l}\text { Akreditas } \\
\text { Kelulusan }\end{array}$ & $\begin{array}{c}\text { Jumlah } \\
\text { Siswa Tuntas }\end{array}$ & Keterangan \\
\hline Sangat Baik & 6 & $16.21 \%$ & $16.21 \%$ & \multirow[t]{3}{*}{33 tuntas } & \multirow{2}{*}{$\begin{array}{l}\text { Telah mencapa } \\
\text { target ketuntasan }\end{array}$} \\
\hline Baik & 11 & $29.73 \%$ & $29.73 \%$ & & \\
\hline Cukup & 16 & $43.24 \%$ & $43.24 \%$ & & di atas \\
\hline Kurang & 4 & $10.82 \%$ & - & \multirow[t]{2}{*}{4 tidak tuntas } & \multirow{3}{*}{$\begin{array}{l}\text { penelitian } \\
\text { dilanjutkan ke } \\
\text { siklus II }\end{array}$} \\
\hline Sangat Kurang & 0 & $0 \%$ & - & & \\
\hline Jum & & $100 \%$ & $89.18 \%$ & 37 orang & \\
\hline
\end{tabular}

Berdasarkan tabel 2, maka ketuntasan hasil belajar teknik dasar lompat jauh gaya jongkok pada siklus I dalam bentuk gambar diagram dapat dilihat pada gambar 1 .

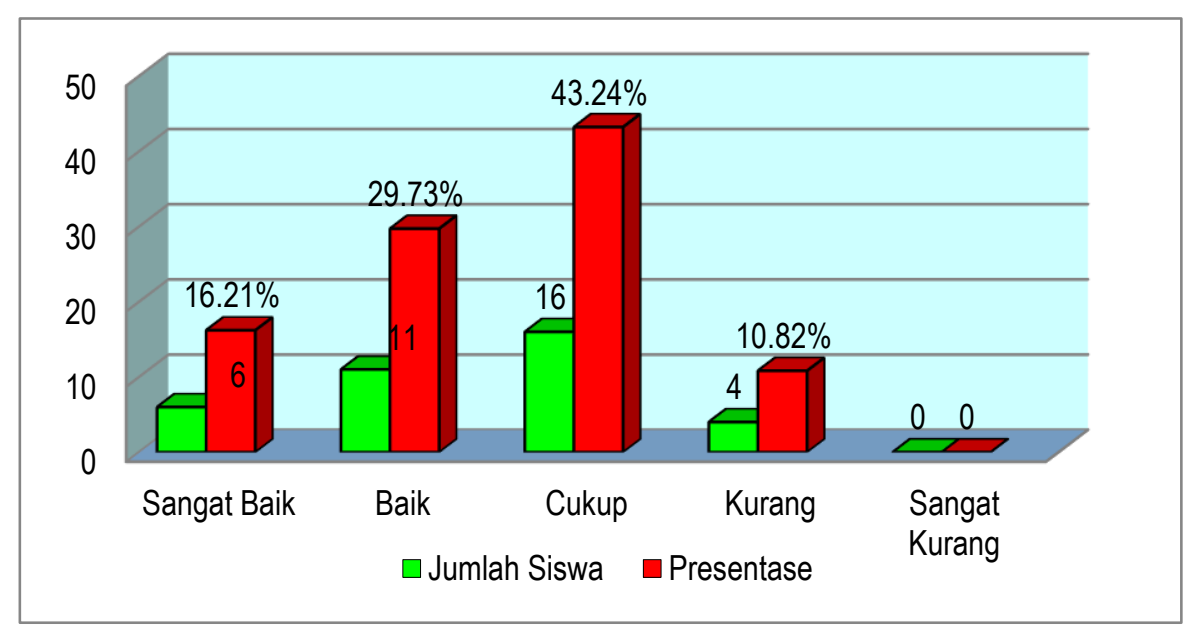

Gambar 1. Diagram Presentase Hasil Belajar Teknik Dasar Lompat Jauh Gaya Jongkok pada Siklus I

Adapun nilai rata-rata skor hasil belajar lompat jauh gaya jongkok dari ketiga evaluator secara klasikal adalah sebagai berikut.

$\bar{X}=\frac{\sum X}{N}=\frac{2879.8}{37}=77.38 \%$

Ketuntasan belajar siswa secara klasikal untuk materi lompat jauh gaya jongkok adalah sebagai berikut.

$K B=\frac{\text { jumlah siswa tuntas }}{\text { jumlah siswa keseluruhan }} \times 100 \%=\frac{33}{37} \times 100 \%=89.18 \%$

\section{Hasil Penelitian Siklus II}

Berdasarkan analisis data hasil belajar pada Siklus II dengan materi teknik dasar lompat jauh gaya menggantung di udara, maka dapat dikelompokkan dalam kategori 
pada tabel 3 sebagai berikut.

Tabel 3. Persentase Kategori Ketuntasan Hasil Belajar Secara Individu Lompat Jauh Gaya Menggantung di Udara Siswa Kelas VIII D2 SMP Negeri 1 Sawan pada Siklus II

\begin{tabular}{|c|c|c|c|c|c|}
\hline Kategori & Jumlah & Persentase & $\begin{array}{l}\text { Akreditas } \\
\text { Kelulusan }\end{array}$ & $\begin{array}{c}\text { Jumlah } \\
\text { Siswa Tuntas }\end{array}$ & Keterangan \\
\hline Sangat Baik & 2 & $5.41 \%$ & $5.41 \%$ & \multirow[t]{3}{*}{35 tuntas } & \multirow{2}{*}{ Telah mencapai } \\
\hline Baik & 31 & $83.78 \%$ & $83.78 \%$ & & \\
\hline Cukup & 2 & $5.41 \%$ & $5.41 \%$ & & \multirow{3}{*}{$\begin{array}{l}\text { ketuntasan } \\
\text { atas } \\
\text { penelitian }\end{array}$} \\
\hline Kurang & 1 & $2.7 \%$ & - & \multirow[t]{2}{*}{2 tidak tuntas } & \\
\hline Sangat Kurang & 1 & $2.7 \%$ & - & & \\
\hline Jum & & $100 \%$ & $94.6 \%$ & 37 orang & $\begin{array}{l}\text { penelitian } \\
\text { dihentikan }\end{array}$ \\
\hline
\end{tabular}

Berdasarkan tabel 3, maka ketuntasan hasil belajar teknik dasar lompat jauh gaya menggantung di udara pada siklus II dalam bentuk diagram dapat dilihat pada gambar 2.

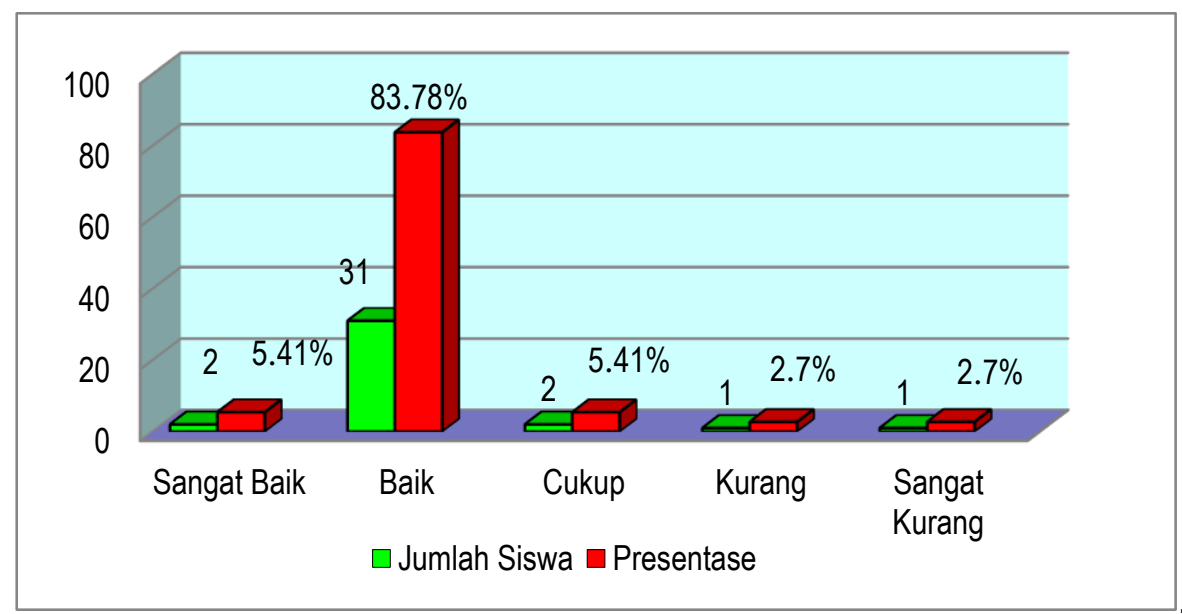

Gambar 2. Diagram Presentase Hasil Belajar Teknik Dasar Lompat Jauh Gaya Menggantung di Udara pada Siklus II

Adapun nilai rata-rata skor hasil belajar lompat jauh gaya menggantung di udara dari ketiga evaluator secara klasikal adalah sebagai berikut.

$\bar{X}=\frac{\sum X}{N}=\frac{2918}{37}=78.87 \%$

Ketuntasan belajar siswa secara klasikal untuk materi lompat jauh gaya jongkok adalah sebagai berikut.

$K B=\frac{\text { jumlah siswa tuntas }}{\text { jumlah siswa keseluruhan }} \times 100 \%=\frac{35}{37} \times 100 \%=94.59 \%$ 
I Komang Adi Palgunadi, Putu Citra Permana Dewi, Kadek Dian Vanagosi \& I Made Bagia | Model Pembelajaran Kooperatif Tipe Team Assisted Individualization (TAI) Pada Pembelajaran Teknik Dasar Lompat Jauh

Berdasarkan analisis data siklus I dan siklus II, maka rata-rata ketuntasan belajar secara klasikal adalah sebagai berikut.

$\bar{X}=\frac{\text { Siklus } 1+\text { Siklus } 2}{2}=\frac{89.18 \%+94.59 \%}{2}=91.88 \%$

\section{PEMBAHASAN}

Melihat hasil penelitian pada siklus I, nilai rata-rata skor hasil belajar lompat jauh gaya jongkok dari ketiga evaluator secara klasikal adalah 77.83\%. Berdasarkan kriteria tingkat penguasaan kompetensi SMP Negeri 1 Sawan, maka nilai rata-rata siswa dari ketiga evaluator secara klasikal diatas termasuk kedalam kategori Cukup. Dari analisis data hasil belajar pada siklus I, maka ketuntasan belajar siswa secara klasikal untuk materi lompat jauh gaya jongkok adalah 89,18\%. Dengan demikian dapat disimpulkan pada siklus I tingkat penguasaan materi secara klasikal terhadap materi lompat jauh gaya jongkok sebesar 89,19\% dengan kategori Baik. Dengan tercapainya penguasaan materi 89,19\% maka penelitian dilanjutkan ke siklus II dengan materi teknik dasar lompat jauh gaya menggantung di udara, karena pada siklus I telah mencapai ketuntasan belajar secara klasikal di atas $75 \%$.

Berdasarkan tabel 1, walaupun sudah memenuhi target ketuntasan $75 \%$ secara klasikal tetapi masih terdapat 4 orang siswa yang tidak tuntas dalam pembelajaran lompat jauh gaya jongkok pada siklus I. Masalah yang dihadapi yaitu (1) pada awalan lompat jauh gaya jongkok siswa saat berlari badannya kurang condong kedepan, (2) pada tumpuan lompat jauh gaya jongkok siswa kurang mengayun tangannya sehingga belum bisa menghasilkan lompatan yang sempurna, (3) pada saat sikap badan di udara badan kurang dibungkukkan kedepan dan kaki kurang di tekuk, sehingga belum menghasilkan gaya yang diharapkan, (4) pada saat melakukan sikap mendarat berat badan tidak di bawa ke depan, sehingga yang mendarat terlebih dahulu adalah bagian tubuh yang dibelakang. Berdasarkan masalah-masalah diatas, maka tindakan perbaikan yang dilakukan yaitu lebih memberikan pemahaman tentang awalan, tumpuan, sikap melayang di udara dan mendarat lompat jauh gaya jongkok sesuai dengan indikator yang belum terpenuhi, sehingga siswa dapat memperbaiki gerakan yang salah menjadi gerakan yang benar.

Setelah dilanjutkan ke siklus II nilai rata-rata skor hasil belajar teknik dasar lompat jauh gaya menggantung di udara dari ketiga evaluator secara klasikal adalah 78,87\%. Berdasarkan kreteria tingkat penguasaan kompetensi SMP Negeri 1 Sawan, maka nilai 
rata-rata siswa dari ketiga evaluator secara klasikal diatas termasuk kedalam kategori Cukup. Dari analisis data hasil belajar pada siklus II, maka ketuntasan belajar siswa secara klasikal untuk materi teknik dasar lompat jauh gaya menggantung di udara adalah $94,59 \%$. Dengan demikian dapat disimpulkan bahwa pada siklus II tingkat penguasaan materi secara klasikal terhadap materi teknik dasar lompat jauh gaya menggantung di udara sebesar 94,59\% dengan kategori Sangat Baik. Dengan tercapainya penguasaan materi $94,59 \%$, maka penelitian dihentikan karena pada siklus II telah mencapai ketuntasan belajar secara klasikal di atas $75 \%$. Peningkatan hasil belajar pada siklus kedua menunjukkan bahwa metode TAI memberikan pengaruh yang positif terhadap hasil belajar.

Hasil penelitian serupa yang dilakukan oleh Trimantara (2020) juga mengalami peningkatan hasil belajar PJOK pada siklus kedua dengan menerapkan model pembelajaran yang sama. Model pembelajaran adalah suatu perencanaan atau suatu pola yang digunakan sebagai pedoman dalam merencanakan pembelajaran di kelas (Trianto, 2007). Pemilihan model pembelajaran mempertimbangkan karakteristik tiap kelas untuk dapat mencapai tujuan pembejaran sehingga hasil belajar siswa dapat mencapai Kriteria Ketuntasan Minimum (KKM). Menurut Dimyati \& Mudjiono (2006) hasil belajar merupakan hasil dari interaksi tindak belajar dan mengajar. Berdasarkan hal tersebut interaksi antar guru dan siswa akan mempengaruhi dari hasi belajar.

Berdasarkan analisis data siklus I dan siklus II, maka rata-rata ketuntasan belajar secara klasikal adalah 91,88\%. Dengan demikian dapat disimpulkan bahwa tingkat penguasaan materi secara klasikal terhadap materi teknik dasar lompat jauh sebesar $91,88 \%$ dengan kategori sangat baik. Peningkatan ketuntasan belajar siswa dari siklus pertama ke siklus kedua sebanyak dua orang siswa. Hasil ini sejalan dengan hasil penelitan secara eksperimen yang dilakukan oleh Ishak \& Supriadi (2018) menunjukkan ada peningkatan hasil belajar teknik shooting permainan sepak bola yang signifikan dengan menggunakan metode pembelajaran team assisted individualization (TAI). Metode pembelajaran TAI ini merupakan salah satu metode pembelajaran yang dapat dijadikan sebagai alternatif untuk membantu siswa dalam menuntaskan hasil belajar khususnya pembelajaran pendidikan jasmanai kesehatan dan olahraga di sekolah. Hal ini dibuktikan dengan beberapa hasil penelitian yang telah dilakukan diantaranya penelitian yang dilakukan oleh Kresnayadi et al. (2019), yang menggunakan metode TAI untuk 
I Komang Adi Palgunadi, Putu Citra Permana Dewi, Kadek Dian Vanagosi \& I Made Bagia | Model Pembelajaran Kooperatif Tipe Team Assisted Individualization (TAl) Pada Pembelajaran Teknik Dasar Lompat Jauh

meningkatkan motivasi dan hasil belajar lay-up shoot bola basket. Selain itu, penelitian yang dilakukan oleh Ardianto (2017) juga menghasilkan dampak yang positif terhadap hasil belajar lompat jauh gaya berjalan di udara pada siswa sekolah menengah atas. Kemampuan tersebut dapat dioptimalkan dengan menerapkan model pembelajaran yang memberikan kesempatan kepada siswa untuk saling berdiskusi dan berinteraksi sehingga kemampuan komunikasi dapat meningkat, yaitu dengan menggunakan pembelajaran kooperatif tipe team assisted individualization (TAl).

\section{SIMPULAN}

Berdasarkan hasil analisis dan pembahasan dapat disimpulkan bahwa hasil belajar teknik dasar lompat jauh (gaya jongkok dan gaya menggantung di udara) siswa kelas VIII D2 SMP Negeri 1 Sawan pada tahun pelajaran 2010/2011 meningkat melalui penerapan model pembelajaran kooperatif tipe team assisted individualization.

Disarankan kepada guru penjasorkes dapat menerapkan model pembelajaran kooperatif tipe TAI pada pembelajaran, karena terbukti efektif untuk meningkatkan hasil belajar teknik dasar lompat jauh. Bagi sekolah dapat dijadikan sebagai pedoman dalam pembelajaran pendidikan jasmani, olahraga dan kesehatan, khususnya pada materi teknik dasar lompat jauh guna meningkatkan hasil belajar siswa. Penelitian lebih lanjut dapat mengungkap tentang pengunaan motel kooperatif tipe TAl dengan jenis cabang olahraga lain, atau membandingkan dua model berbeda dalam pembelajaran penjasorkes di level yang lebih tinggi.

\section{REFERENSI}

Ardianto, F. (2017). Meningkatkan hasil belajar lompat jauh gaya berjalan di udara melalui model pembelajaran team assisted individualization pada siswa kelas XI IIS 3 SMA Negeri 1 Sukoharjo Tahun pelajaran 2016/2017.

Asma, N. (2006). Model pembelajaran kooperatif. Jakarta: Depdiknas.

Bari, T. S. (2017). Penerapan Model Pembelajaran Kooperatif Tipe Team Assisted Individualization (TAI) Untuk Meningkatkan Hasil Belajar Dribbling Bola Basket Pada Siswa Kelas Xi Sma Negeri 5 Kota Tanjung Balai Tahun Ajaran 2017/2018. UNIMED.

Budi, D. R., Hidayat, R., \& Febriani, A. R. (2019). The Application of Tactical Approaches in Learning Handballs. JUARA: Jurnal Olahraga. https://doi.org/10.33222/juara.v4i2.534 
Budi, D. R., \& Listiandi, A. D. (2021). Model Pembelajaran Dalam Pendidikan Jasmani. https://doi.org/https://doi.org/10.31219/osf.io/xzh3g

Cahyaningsih, S. N. (2016). Penerapan Model Pembelajaran Tai (Team Assisted Individualization) untuk Meningkatkan Hasil Belajar Passing Bola Basket pada Peserta Didik Kelas VII G SMP N 14 Surakarta Tahun Pelajaran 2016/2017.

Dimyati \& Mudjiono. (2006). Belajar dan pembelajaran. Jakarta: Rineka Cipta.

Djumidar. (2007). Gerak-gerak Dasar Atletik dalam Bermain. Jakarta: Rajawali Sport.

Eddy Purnomo, D. (2011). Dasar-Dasar Gerak Atletik. Yogyakarta: Allamedia.

Indrawathi, N. L. P., Dewi, P. C. P., Widiantari, N. L. G., \& Vanagosi, K. D. (2021). FaktorFaktor yang Mempengaruhi Hasil Belajar Pendidikan Jasmani, Olahraga dan Kesehatan pada Siswa Kelas VII SMP Negeri 5 Kuta Selatan. Jurnal Pendidikan Kesehatan Rekreasi, 7(1), 239-247.

Ishak, M., \& Supriadi, D. (2018). Peningkatan Teknik Shooting Melalui Model Pembelajaran TAI. JUDIKA (Jurnal Pendidikan UNSIKA), 6(2), 59-68.

Iskandar, D. (2015). Penelitian Tindakan Kelas dan Publikasinya. Ihya Media.

Kanca, I. N. (2010). Metode Penelitian Pengajaran Pendidikan jasmani dan Olahraga. Singaraja: Jurusan IImu Keolahragaan Fakultas Pendidikan IImu Keolahragaan Universitas Pendidikan Ganesha Singaraja. Pair Share.

Kresnayadi, I. P. E., Rusitayanti, N. W. A., Sumerta, I. K., Ariawati, N. W., Sudiarta, I. G. N., \& Bagia, I. M. (2019). Penerapan Model Pembelajaran Kooperatif Tipe Team Assisted Individualization (Tai) Untuk Meningkatkan Motivasi Dan Hasil Belajar Lay Up Shoot Bola Basket. Jurnal Pendidikan Kesehatan Rekreasi, 5(2), 82-88.

Miftahul, H. (2011). Cooperatif Learning. Jakarta: Pustaka Pelajar.

Mulyanto, R. (2014). Belajar dan Pembelajaran Penjas. Bandung: UPI Sumedang Press.

Nur, L., Malik, A. A., Juditya, S., Kastrena, E., Widyawan, D., Agustan, B., ... Yang, C. B. (2020). Comparison of two types of instruction in physical education. International Journal of Psychosocial Rehabilitation, 24(10), 1785-1793. https://doi.org/10.37200/IJPR/V24I10/PR300205

Nurhasan. (1990). Tes dan Pengukuran dalam Penjas serta Prinsip-Prinsip Pelaksanaannya. Jakarta: Depdikbud.

Palgunadi, I. K. A., \& Putra, I. G. N. B. (2020). Penerapan Model Pembelajaran Kooperatif Tipe Team Assisted Individualization (Tai) Untuk Meningkatkan Hasil Belajar Teknik Dasar Menggiring Bola Pada Siswa Kelas VIII K SMP Negeri 1 Mengwi Tahun Pelajaran 2018/2019. Widyadari: Jurnal Pendidikan, 21(2), 588-593. 
I Komang Adi Palgunadi, Putu Citra Permana Dewi, Kadek Dian Vanagosi \& I Made Bagia | Model Pembelajaran Kooperatif Tipe Team Assisted Individualization (TAl) Pada Pembelajaran Teknik Dasar Lompat Jauh

Rosdiani, D. (2012). Model pembelajaran langsung dalam pendidikan jasmani dan kesehatan. Bandung: Alfabeta.

Slavin, R. E. (2005). Cooperative learning teori, riset dan praktik. Bandung: Nusa Media, 236.

Sugiyanto, H. (2010). Model-model pembelajaran inovatif. Surakrta: Yuma Pustaka.

Syarifuddin, A. (1997). Penjasorkes dan Kesehatan. Jakarta: PT Gramedia Widiasarana Indonesia.

Trianto. (2007). Model-model pembelajaran inovatif berorientasi Konstruktivistik. Jakarta: Prestasi Pustaka.

Trimantara, I. K. B. B. (2020). Upaya Meningkatkan Hasil Belajar Pjok Melalui Implementasi Model Pembelajaran Tai Pada Siswa Kelas V SD Negeri 9 Subagan. Jurnal IImu Keolahragaan Undiksha, 8(1). 